\title{
Dimensioning the extended capacity of Zlatar Ski Center using linear programming method
}

\author{
Bogdan Marković ${ }^{1}$, Milan Marković ${ }^{1}$, Dragana Velimirović ${ }^{1 *}$ \\ ${ }^{1}$ Academy of Applied Technical Studies - College of Traffic, Mechanical Engineering and \\ Safety Engineering, Belgrade, Serbia
}

\begin{abstract}
Zlatar Ski Center has an extremely high potential as a ski resort that could be among the most visited ones in Serbia. What characterizes this center is the proximity of Kokin Brod Lake, the Tara River and the like. Therefore, Zlatar should be considered both as a ski center and in terms of other diversities. The aim of this paper is to analyze the pos sibility of expanding the capacity of ski resorts by increasing the pos sible flow of skiers on new ski lifts and ski slopes. The methods used in this paper belong to operational research, specifically, the geometric interpretation of linear programming. It is also shown how to optimize the extended capacities. If the capacities of ski slopes are to be increased, it would initiate greater investment in accommodation capacities in the area of the municipality of Nova Varoš, which would affect its improvement in terms of tourism.
\end{abstract}

Keywords: linear programming, ski lifts and ski slopes, optimization of extended capacity JEL classification: $\mathrm{C} 44, \mathrm{Z} 32$

\section{Primena linearnog programiranja na dimenzioniranje proširenog kapaciteta ski centra Zlatar u Novoj Varoši}

Sažetak: Ski centar Zlatar poseduje izuzetno visok potencijalkao skijalište koje bi moglo da bude u rangu najposećenijih u Srbiji. Ono što ovaj centar ističe, i u pozitivnom smislu izdvaja od drugih, je blizina jezera Kokin Brod, reke Tare i slično. Prema tome, Zlatar ne bi trebalo razmatrati samo kao ski centar, već i sa as pekta posedovanja i drugačijih diverziteta. Cilj rada je analiza mogućnosti proširenja kapaciteta skijališta povećanjemmogućeg protoka skijaša na žičarama i kapaciteta žičara. U tom smis lu, predviđa se i povećanje broja staza, kao i interkonekcija između njih. Metode koje su korišćene u radu pripadaju operacionim is traživanjima, konkretno, geometrijs ka interpretacija linearnog programiranja. Prikazano je da je na ovaj način moguće optimizovati proširene kapacitete. Povećani kapacitet ski staza inicirao bi veće ulaganje u smeštajne kapacitetena prostoru opštine Nova Varoš, čime bi se uticalo na njeno unapređenje $u$ turis tičkom smislu.

*vps.draganavl@gmail.com

This article is an open access article distributed under the terms and conditions of the Creative Commons Attribution (CC BY) license (http://creativecommons.org/licenses/by/4.0/). 
Ključne reči: linearno programiranje, ski liftovi i ski staze, optimizacija proširenog kapaciteta

JEL klasifikacija: C44, Z32

\section{Introduction}

The paper provides an approach to establishing the required number of lifts in the case of expansion of Zlatar Ski Center as suming an increase in the number of ski slopes. The starting point is that the chair lift that supplies more ski slopes must not have a capacity greater than the capacity of the ski slope with the lowest capacity that gravitates to that lift. The reas on is a security as pect (Wheeler, 2012). In the event that some of the ski slopes are closed and the capacity of the chair lift to which these ski slopes gravitate is fulfilled, skiers would be directed to one or more of the remaining ski slopes in service. In that case, the open ski slopes that are in service should not be overloaded. The flow of skiers should not be higher than the maximum availability of the ski slopes (Poulhès \& Miria, 2017; Revilloud et al., 2011). For this reason, the sizing of the chair lifts is realized in the stated way. In the following chapters a model for sizing the capacity of lifts in accordance with the existing system of ski slopes and the projected capacity of new ones (Wheeler, 2012) will be provided.

The main hypothesis of this res earch is that it is possible to resize the capacity of Zlatar Ski Center, and based on mathematical model and linear programming implementation the optimal solution of extended model dimensioning of ski slopes and ski lifts could be calculated.

Optimization of tourist capacities with the necessary logistics is permanently present topic (Jangra \& Kaushik, 2021), and the application of the linear programming for that purpose was considered in papers published before (Borrelli et al., 2003; Knijff \& Oosterhaven, 1990).

\section{Mathematical models for ski slopes capacity dimensioning}

The capacity of a ski lifts systemis projected by applying flow analysis and Kirchhoff's rule that total input to the system is equal to the output from it. It is necessary to res pect the equation of flow continuity (Mađarević, 1969). The flow of skiers on the ski lifts is the function of the capacity of ski slopes by which the system is getting relieved. Chair ski lifts that lead to the peaks have the largestcapacity. They are directed from the accommodation facilities, like hotel complex or ski bus terminus to the highest peaks. From these points, there is a flow divergence to s maller capacity $\mathrm{T}$ - bar type ski lifts, which cover the complex of ski slopes (Marković, 2019a; Suvajdžić, 1972). According to the fact that the organization of skiers' flow is the main activity in the considered area (Zrnić, 1993), ski center represents a big system of internal transport.

\subsection{Chair lift dimensioning}

The capacity of ski lifts is dimensioned on the bas is of the required flow of skiers, i.e. the available accommodation capacity of the hotel or the capacity of the bus line by which the skiers are brought to the starting point of the chair lifts. The capacity of the ski lifts leading from the starting point is the largest and matches the sum of capacities of smaller ski lifts (often T-bar type) which gravitate to the ski slopes capacity. According to that, the pos sibility of shifting skiers fromone ski slope to the other has also to be considered. It is important that percentage of such flows must not exceed the maximum allowed ski slope capacity. Presentation of such a situation is provided for a hy pothetical ski center in Table 1 and Figure 1 (Marković, 2019a). 
Table 1 represents the schema for the share of skiers per hour crossing from one ski slope (rows) to the other (columns). Values in the cells are expressed in percentage of the maximum capacity of the ski slope, in skiers per hour that are expected to cross from one slope to another.

Table 1: Share of skiers perhour (\%) crossings fromone ski slope to another and ski slopes capacity of a hypothetic ski center

\begin{tabular}{|c|c|c|c|c|c|c|c|c|c|}
\hline Ski slopes & $\mathbf{1}$ & $\mathbf{2}$ & $\mathbf{3}$ & $\mathbf{4}$ & $\mathbf{5}$ & $\mathbf{6}$ & $\mathbf{7}$ & $\mathbf{8}$ & $\begin{array}{c}\text { Capacity } \\
\text { [skiers/h] }\end{array}$ \\
\hline $1 \rightarrow$ & & 0 & 0 & 10 & 10 & 5 & 10 & 0 & 1000 \\
\hline $2 \rightarrow$ & 5 & & 0 & 0 & 0 & 5 & 5 & 5 & 2000 \\
\hline $3 \rightarrow$ & 10 & 5 & & 5 & 0 & 0 & 0 & 0 & 3000 \\
\hline $4 \rightarrow$ & 5 & 10 & 0 & & 0 & 0 & 5 & 10 & 1000 \\
\hline $5 \rightarrow$ & 0 & 0 & 5 & 20 & & 0 & 0 & 0 & 1000 \\
\hline $6 \rightarrow$ & 0 & 0 & 5 & 0 & 5 & & 5 & 5 & 500 \\
\hline $7 \rightarrow$ & 5 & 0 & 5 & 10 & 0 & 5 & & 0 & 2000 \\
\hline $8 \rightarrow$ & 0 & 0 & 10 & 0 & 0 & 0 & 0 & & \\
\hline
\end{tabular}

Source: Author's research

For example, the estimated share percentage of skiers crossing from the first ski slope to Slope 4, 5 and 7 is maximum $10 \%$, while only $5 \%$ could be transferred to Slope 7 . Accordingly, the capacity of each ski slope on which crossing is assumed has to be boosted according to enlarged number of skiers per hour. A similar approach is to be applied for other ski slopes (Marković, 2019a). In the case of designing a new ski slope, No. 8, which gravitates to the chair lift 2 from direction 1 and to the chair lift 1 from the same direction, including the inflow of skiers from other ski slopes, the layout will be as presented by scheme, Figure 1 (Marković, 2019a).

Figure 1: Ski slope 8 loading, by chair lifts and by adjacent ski slopes

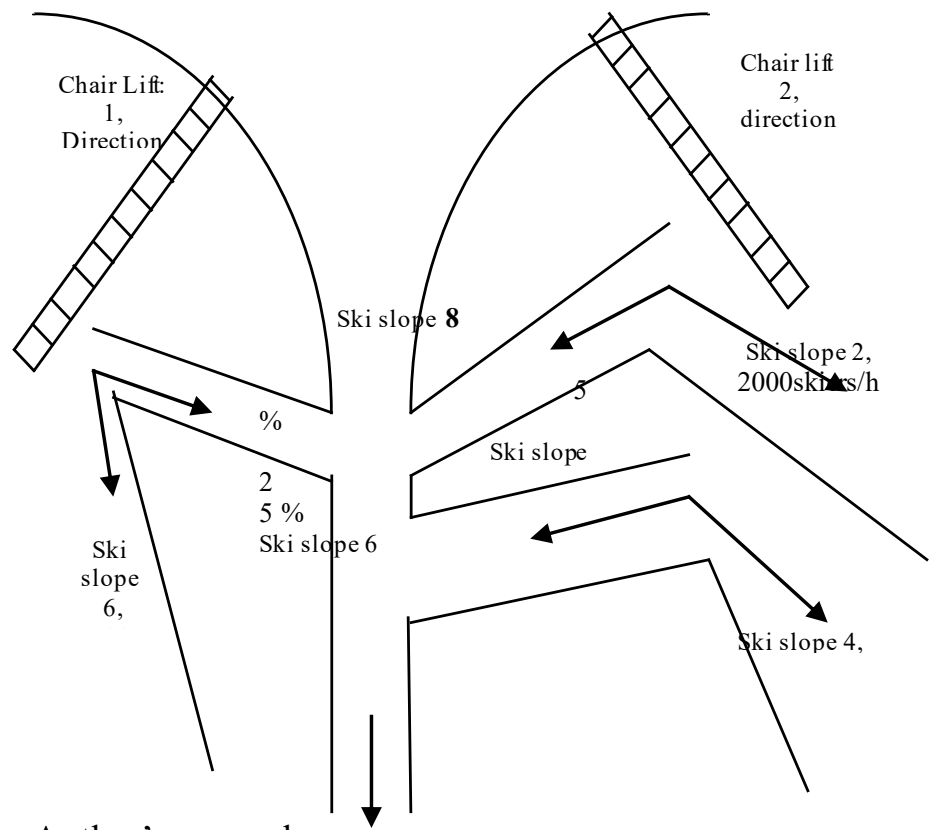

Source: Author's research 
Required capacity on the $j$ of the total: $n$ directions from the center of the ski resort, $n=3$; I, II and III direction, to the peaks is as follows:

$$
Q_{j}[\text { skiers } / h] \leq \sum_{i=1}^{m} q_{j i}
$$

where:

- $q_{j i}[$ skiers/h] - capacity of the $i$ ski lift in the $j$ direction,

- $m$ - total number of ski lifts in the $j$ direction.

The total flow of all ski lifts in skiers per hour is expressed by:

$$
\sum_{g=1}^{s} Z_{g}=\sum_{j=1}^{n} \sum_{i=1}^{m} q_{j i}
$$

\subsection{Ski slopes dimensioning}

Neces sary capacity $t_{g}$ of the ski s lope $g$ represents the projected hourly flow of skiers on that ski slope in the form:

where:

$$
t_{g}[\text { skiers } / h]=\sum_{j=1}^{l} Z_{g j}[\text { skiers } / h]+\sum_{i=1}^{s} p_{g i} \cdot Z_{i}[\text { skiers } / h],
$$

- $s$-total number of skis lopes,

- $\quad Z_{g}$ [skiers/h]- projected hourly flow of skiers on ski lifts to which the $g$ ski slope gravitates,

- $\quad p_{g}[\% / 100]-$ the share of capacity expres sed through the hourly flow of skiers crossing from $i$ ski slope to the $g$ ski slope,

- $\quad Z_{i}[$ skiers $/ \mathrm{h}]$ - projected hourly flow of skiers on $i$ ski slope,

- $\quad l$ - total number of ski lifts by which the ski slope gravitates.

The capacity of all ski slopes is in the form:

$$
T[\text { skiers } / h]=\sum_{g=1}^{\text {totalNo of all ski slopes }} t_{g} .
$$

\section{Design of necessary chairlifts and ski slopes capacity}

Since the aim of this paper is analysis of possible capacity expansion of Zlatar Ski Center, it is neces sary to present the current situation first. Zlatar Ski Center current state is represented in Figure 2 with ski slopes I and II, as well as the four-seat chairlift that leads from foot to the top, together with T-bar ski lift that leads from the fork point $b_{1}$ to the peak point $a_{1}$. Peak point $\mathrm{a}_{1}$ is top point to which it is pos sible to get from the foot of the mountain as well as from the middle fork point: $b_{1}$, Figure 2 . This paper estimates that in addition to the mentioned peak point and middle fork point $b_{1}$, new peak points should be designed: $a_{2}$ and $\mathrm{a}_{3}$, Figure 2. Skiers will be able to get to these points from the new base point $\mathrm{S}$ by newly designed chairlifts: 2,3 and 4 as suggested in Figure 2. Skiers are expected to access several newly designed ski slopes, i.e. III to VI from top points $\mathrm{a}_{2}$ and $\mathrm{a}_{3}$, and fromthose new slopes middle points $b_{\text {, to }} b_{5}$, Figure 2, skiers would be able to get to the top again by newly designed smaller capacity T-bar type ski lifts. According to that, skiers are not forced to descend to the base point in order to reach the top points again by high capacity ski lifts, but 
with smaller capacity, T-bar type ones. Considering the unused benefits of this ski center due to high snow amount and average number of snow days during the year, Table 2, this paper proposes a solution to the possible capacity expansion of this skicenter by introducing new fork points, new ski slopes and ski lifts as described.

Table 2: Average snowfall at Zlatar

\begin{tabular}{|c|c|c|}
\hline Month & Snow amount (week) & Snow days (week) \\
\hline December & $16 \mathrm{~cm}$ & 2.8 days \\
\hline January & $20 \mathrm{~cm}$ & 3.3 days \\
\hline February & $22 \mathrm{~cm}$ & 3.5 days \\
\hline March & $23 \mathrm{~cm}$ & 3.4 days \\
\hline April & $10 \mathrm{~cm}$ & 1.6 days \\
\hline
\end{tabular}

Source: Snow-forecast (2021)

According to the abovementioned, newly designed $\mathrm{T}-$ bar ski lifts would be used for taking skiers from mid-points $\mathrm{b}_{i}, i=2, \ldots n, n=5$ to points $\mathrm{a}_{i}, i=2,3$ on the peak as they will not be forced to take chairlift from the starting point $S$, Figure 2.

Altogether, the existing and newly designed layout of the Zlatar Ski Center is shown in Figure 2. The full lines show ski slopes, the dashed lines represent newly designed chairlifts in the directions toward $\mathrm{a}_{2}$ and $\mathrm{a}_{3}$ points. The Arabic numerals refer to chairlifts while Rome numerals refer to ski slopes.

Figure 2: Zlatar Ski Center, existing and newly designed layout

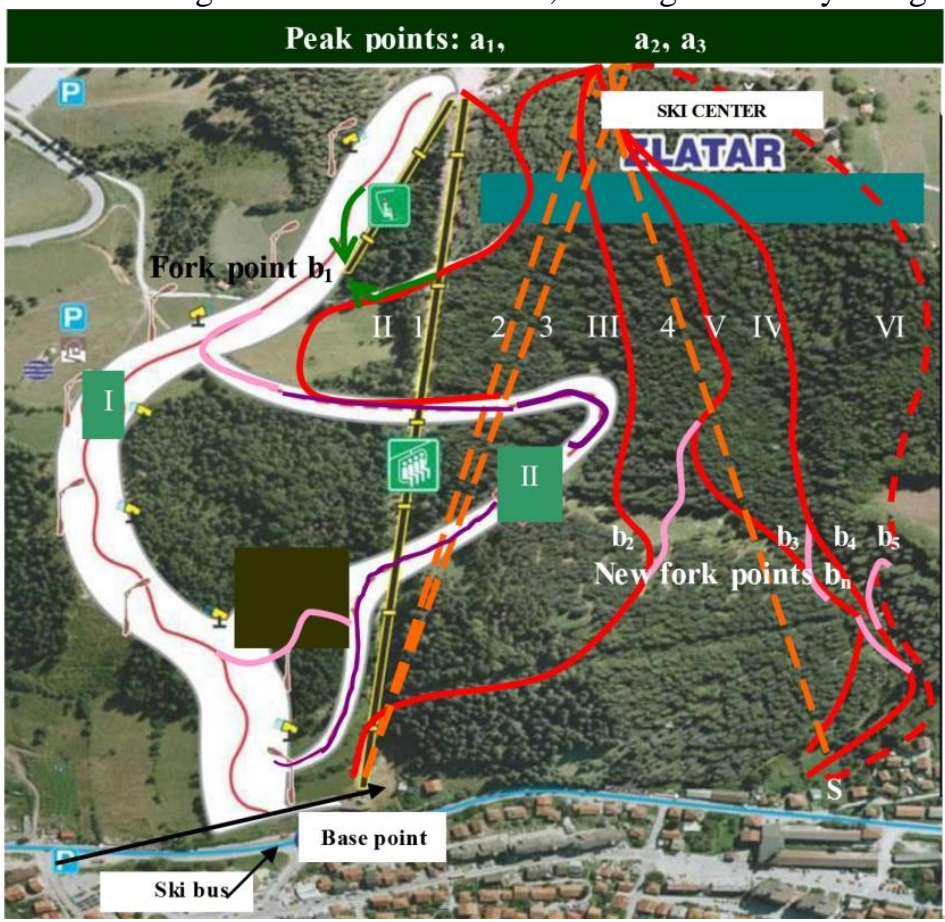

Legend

I, II... - ski slope sign,

$1,2 \ldots$ - the sign of the chairlift to the first forks $-\mathrm{a}_{1}, \mathrm{a}_{2}$, and $\mathrm{a}_{3}$,

- - existed ski slope,

- = - chairlift, new,

- ski crossway,

- existing chair lift

- ski crossway to fork point $b_{1}$,

- crossway from chairlift to slope,

- newly designed ski slope,

- - - ski slope which is yet to be designed,

- road to ski bus,

S - newly designed start point.

Source:ZlatarInfo Portal, Kornjacos, Tech(2021)

In order to increase the number of ski slopes and the chair lifts of Zlatar Ski Center, a new starting point is planned towards the fork points $\mathrm{a}_{2}$ and $\mathrm{a}_{3}$, as well as the crossing from one ski slope to another, Table 1 and Figure 2. 
Newly designed concept introduces the expansion of the capacity of the Center, where it is necessary to harmonize the capacity of the newly designed ski slopes and the required capacity of the newly designed chairski lifts, which leads to the optimization of the existing conditions. The required capacity of each of the four newly designed chair lifts that supply five ski slopes of the newly designed Ski center Zlatar is established. Ski center is to be designed with the ski slopes capacity of 1000, 2000, 3000, 2000 and 4000 skiers per hour.

The criterion for determining the required capacity of the ski lift is the fulfillment of the conditions that the capacity of the ski lift must be at maximum, but not higher than the capacity of the skis lope with the lowest through pass, comparing the through passes of all ski slopes that gravitate to that ski lift.

On the other hand, the capacities of chair lifts that supply a particular peak point "a", Figure 2 , must be approximately equal to the capacity of all smaller capacity $\mathrm{T}$-bar ski lifts that gravitate to the point "a". The canacitv of chair lifts is in correlation to the capacity of the ski slopes that gravitate to them and is to be establis hed in chapters that follow.

The required capacity of each of the newly designed chair lifts, including theexis ting one, is being established. The calculation is also realized in compliance with the principle that the total capacity of chair lifts that supply ski slopes must notbe greater than the capacity of the lowest capacity ski slope from the as pect of the hourly flow of skiers. When performing the calculation (Marković, 2019a), the shifting of skiers from one ski slope to another is not foreseen while the chair lifts supply the ski slopes in the following way: ski lift No. 1 supplies the ski slopes 1 and 2; ski lift No. 2, supplies the ski slopes 2, 4, and 5; ski lift No. 3, supplies the ski slopes 3,4 and 5; and ski lift No. 4, supplies the ski slope 5 as well as the newly designed one, i.e. No. 6, Figure 3.

Figure 3: Ski center scheme

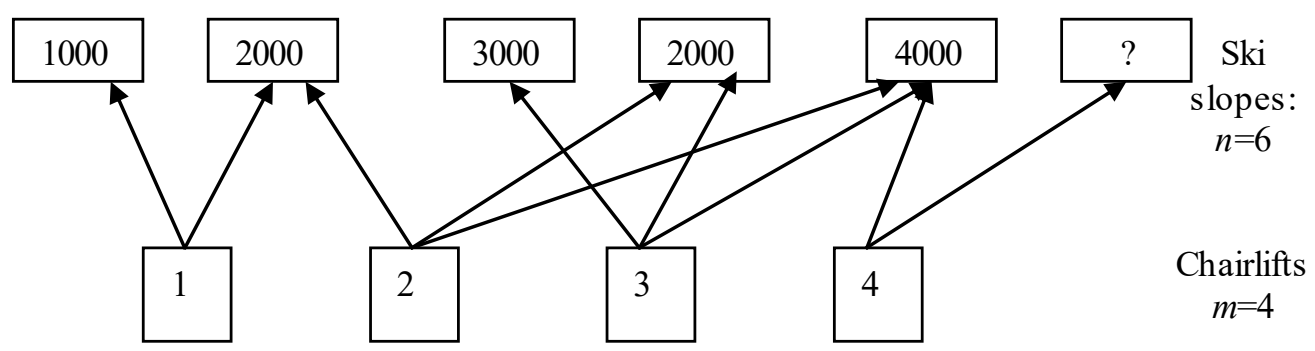

Source: Author's research

It is not allowed to achieve influx of skiers on the ski slope greater than its capacity. On the basis of this, through the geometric interpretation of linear programming (Nadler, 1973; Marković, 2019b; Borrelli et al., 2003; Kas ana \& Kumar, 2004), inequalities are formed for the maximum capacity (Nash \& Sofer, 1996; Sarbjit, 2018) of each ski slope: $i, i=1, \ldots, n=5$, in the form:

$$
\begin{gathered}
C_{1} \leq 1000, \text { for ski slope } 1, \\
C_{1}+C_{2} \leq 2000 \Rightarrow C_{2} \leq 2000-C_{1} \text {, for ski slope } 2, \\
C_{3} \leq 3000, \text { for ski slope } 3,
\end{gathered}
$$




$$
\begin{gathered}
C_{2}+C_{3} \leq 2000, \text { for ski slope } 4, \\
\Rightarrow C_{3} \leq 2000-C_{2}, C_{3} \geq 0 \Rightarrow 2000-C_{2} \geq 0 \Rightarrow C_{2} \leq 2000, \\
C_{2}+C_{3}+C_{4} \leq 4000, \text { for ski slope } 5 \\
C_{4} \leq 4000-\left(C_{2}+C_{3}\right), C_{4} \geq 0 \Rightarrow \\
4000-C_{2}-C_{3} \geq 0, C_{3} \geq 0 \Rightarrow C_{2} \leq 4000
\end{gathered}
$$

Inequalities follow in the next form:

$$
C_{1} \leq 1000, C_{2} \leq 1000 \text {, and } C_{i} \geq 0, i=1, \ldots, m, m=4
$$

In this case $C_{i}, i=1, \ldots, m, m=4$, represent the capacities of the ski lifts (Dedijer, 1983) that should weigh the highest possible value, whereby it is not pos sible to supply the ski slopes with the flow of skiers that exceed the capacity of the ski slope. It has to be noted that the requirement is that the capacity of the ski slope must not be exceeded even in the case of closing one of the ski slopes that are supplied by the same chair lift.

The objective function that represents themaximum flow of skiers on all ski slopes of the ski resort, and should strive for the maximum value is in the form:

$$
0 \leq F_{c}=\sum_{i=1}^{n=4} C_{i}, i=1 \div 4, F_{c}=C_{1}+C_{2}+C_{3}+C_{4} \rightarrow \max
$$

Hence:

$$
\begin{gathered}
F_{c}=C_{1}+C_{2}+\left(2000-C_{2}\right)+\left(4000-\left(C_{2}+C_{3}\right)\right)= \\
=C_{1}+C_{2}+\left(2000-C_{2}\right)+\left(4000-\left(C_{2}+2000-C_{2}\right)\right) \\
F_{c}=C_{1}+C_{2}+\left(2000-C_{2}\right)+2000=C_{1}+4000, F_{c} \geq 0 .
\end{gathered}
$$

Inequalities (1), (2), (3) and (4) are entered in diagram $C_{1}-C_{2}$, Figure 4. A vertex coordinates of $M_{1}, M_{2}, M_{3}$ and $M_{4}$ represent capacities of chair lifts $1,2,3$, and 4, Figure 4.

Figure 4: Chair lifts capacity domain and capacity of objective function (6)

\section{$F_{C} \neq 0$}

Objective function has its mininum in points $M_{1}$ and $M_{2}$, while its maximum value is reached in $M_{3}$ and $M_{4}$.

The $\vec{\longrightarrow}$ dition that has to be met is:

$$
C_{1}, C_{2}, C_{3}, C_{4}>0
$$

$-4000$

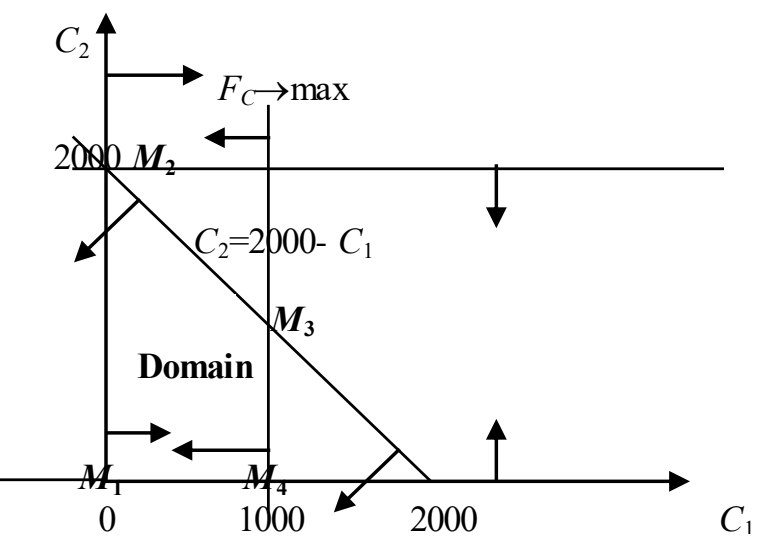

Source: Author's research 
These vertexes form the closed polygonal line that bounds the domain for the chair lifts capacities in skiers per hour, i.e. $C_{1}, C_{2}, C_{3}, C_{4}$, (Marković, 2019a), and are as follows:

$$
\begin{gathered}
M_{i}\left(C_{i 1}, C_{i 2}, C_{i 3}, C_{i 4}\right), i=1,2,3,4 . \\
M_{1}(0,0,2000,2000), M_{2}(0,2000,0,2000), \\
M_{3}(1000,1000,1000,2000), M_{2}(1000,0,2000,2000) .
\end{gathered}
$$

The largest traffic on the chair ski lifts is realized in the vertexes $M_{3}$ and $M_{4}(7)$. As it is not pos sible for traffic on the chair lift to be zero, by the reas on of its abolition in that case, the values of coordinates in vertex $M_{3}$ are to be adopted as adequate. That means that the capacity of the chair lifts will be $C_{1}=1000, C_{7}=1000, C_{3}=1000$ and $C_{4}=2000$ skiers per hour (7). This state is to be considered as optimal.

The coefficient of skis lope utilization from the aspect of cableway capacity is in the form:

$$
\begin{gathered}
k_{i s_{1}}=\frac{C_{1}}{S_{1}}=\frac{1000}{1000}=1 \Rightarrow 100 \%, k_{i s_{2}}=\frac{C_{1}+C_{2}}{S_{2}}=\frac{2000}{2000}=1 \Rightarrow 100 \%, \\
k_{i s_{3}}=\frac{C_{3}}{S_{3}}=\frac{1000}{3000}=0.3 \Rightarrow 30 \%, k_{i s_{4}}=\frac{C_{2}+C_{3}}{S_{4}}=\frac{2000}{2000}=1 \Rightarrow 100 \%, \\
k_{i s_{5}}=\frac{C_{2}+C_{3}+C_{4}}{S_{5}}=\frac{4000}{4000}=1 \Rightarrow 100 \% .
\end{gathered}
$$

Where: $S_{i}$ [skiers/h], $i=1, \ldots, 5$ - capacity of $i$ - ski slope.

Authors of the paper created and ran the program SKIERS 6, based on Williams (2003), taking into account calculations presented in this chapter, (1) to (8). The res ults are presented in the chapter that follows. The difference is that in new cases the percentage of skiers crossing fromone ski slope to the other is also included in account scheme. This option is described in the hypothetical example in chapter 2.

\section{Results of the analysis of ski flows at Zlatar Ski Center, Nova Varoš}

By applying the SKIERS 6 programpackage, the results listed in the files were obtained as follows:

Total capacity of all ski slopes: 12000 [skiers/h]

Total capacity of all chair ski lifts: 5000 [skiers/h]

The percentage utilization of the ski slopes is 41.66666 [\%]

Minimum of the capacity necessary for the ski slope 1 , calculated with no crossing to this ski slope from the others is 1000 [skiers/h]

Minimum of the capacity necessary for the ski slope 2, calculated with no crossing to this ski slope from the others is 2000 [skiers/h]

Minimum of the capacity necessary for the ski slope 3 , calculated with no crossing to this ski slope from the others is 1000 [skiers/h]

Minimum of the capacity necessary for the ski slope 4, calculated with no crossing to this ski slope from the others is 2000 [skiers/h]

Minimum of the capacity necessary for the ski slope 5, calculated with no crossing to this ski slope from the others is 4000 [skiers/h]

Minimum of the capacity necessary for the ski slope 6 , calculated with no crossing to this ski slope from the others is 2000 [skiers/h] 
The scheme of the anticipated percentage of crossings fromeach ski slope to all the others [skiers/h] is as follows:

$\begin{array}{lcccccc}\text { Ski slope } & \text { No. 1 } & \text { No. 2 } & \text { No. 3 } & \text { No. 4 } & \text { No. 5 } & \text { No. 6 } \\ \text { Ski slope No. 1 } & 0 & 200 & 0 & 0 & 0 & 0 \\ \text { Ski slope No. } 2 & 0 & 0 & 0 & 0 & 0 & 0 \\ \text { Ski slope No.3 } & 0 & 0 & 0 & 0 & 0 & 0 \\ \text { Ski slope No.4 } & 0 & 0 & 0 & 0 & 200 & 0 \\ \text { Ski slope No.5 } & 0 & 0 & 800 & 400 & 0 & 0 \\ \text { Ski slope No.6 } & 0 & 0 & 0 & 400 & 0 & 0\end{array}$

Minimum of the capacity necessary for the ski slope 1 is: 1200 [skiers/h] Efficiency coefficient of the ski slope No. 1 is: $\eta(1)=1.2$

Minimum of the capacity neces sary for the ski slope 2 is: 2000 [skiers $/ \mathrm{h}$ ] Efficiency coefficient of the ski slope No. 2 is $: \eta(2)=1$

Minimum of the capacity neces sary for the ski slope 3 is: 1000 [skiers /h] Efficiency coefficient of the ski slope No. 3 is: $\eta(3)=0.3333333$

Minimum of the capacity neces sary for the ski slope 4 is: 2200 [skiers /h] Efficiency coefficient of the ski slope No. 4 is: $\eta(4)=1.1$

Minimum of the capacity necessary for the ski slope 5 is: 5200 [s kiers $/ \mathrm{h}$ ] Efficiency coefficient of the ski slope No. 5 is: $\eta(5)=1.3$

Minimum of the capacity neces sary for the ski slope 6 is: 2400 [skiers $/ \mathrm{h}$ ] Efficiency coefficient of the ski slope No. 6 is: $n(6)=1$

Minimum of the capacity necessary for the all ski slopes is: 14000 [skiers /h]

Efficiency coefficient of all ski slopes from the as pect of the minimum necessary capacity is in the sum of 0.53 .

It is stated that on the ski slopes 1 and 5, the utilization coefficient is higher than one due to the anticipated possibility of skiers crossing fromone ski slope to another. This causes the necessary increase in the capacity of the ski slopes in order to reduce the utilization coefficients of the ski slopes 1 and 5. The improved solution is presented in the scheme of the ski resort, Figure 5.

Figure 5: Ski slopes capacities

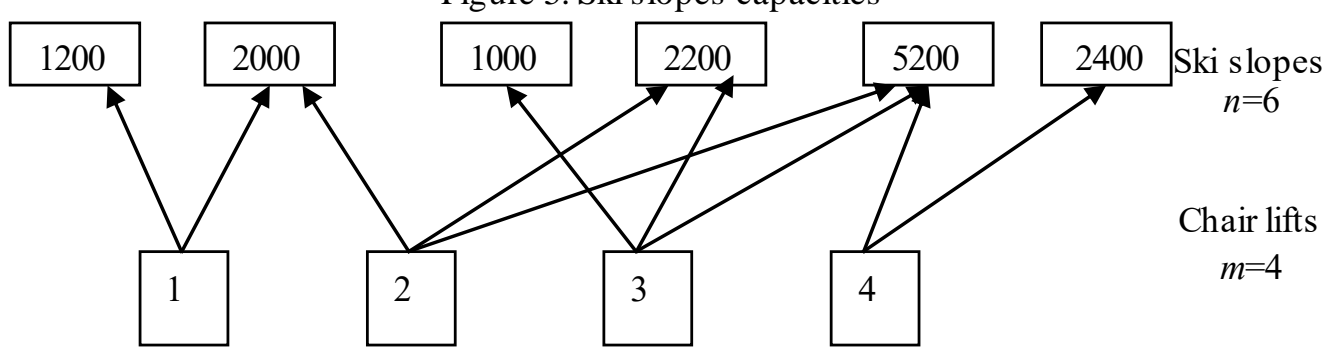

Source: Author's research

Based on Figure 5, through the geometric interpretation of linear programming, inequalities are formed for the maximum capacity of each ski slope: $i, i=1, \ldots, n=6$, in the form that follows:

$$
\begin{gathered}
C_{1} \leq 1200, \text { for ski slope } 1, \\
C_{1}+C_{2} \leq 2000, C_{2} \geq 0 \Rightarrow C_{2} \geq 2000-C_{1} \Rightarrow C_{1} \leq 2000, \text { for ski slope } 2, \\
C_{3} \leq 1000, \text { for ski slope } 3,
\end{gathered}
$$




$$
\begin{gathered}
C_{2}+C_{3} \leq 2200, \text { for ski slope } 4, \\
\Rightarrow C_{3} \leq 2200-C_{2}, C_{3} \geq 0 \Rightarrow 2200-C_{2} \geq 0 \Rightarrow C_{2} \leq 2200, \\
C_{2}+C_{3}+C_{4} \leq 5200, \text { for ski slope } 5, \\
C_{4} \leq 5200-\left(C_{2}+C_{3}\right), C_{4} \geq 0 \Rightarrow 5200-C_{2}-C_{3} \geq 0, C_{3} \geq 0 \Rightarrow C_{2}-5200 \geq 0 \Rightarrow \\
C_{2} \leq 5200, \\
C_{4} \leq 2400, \text { for ski slope } 6 .
\end{gathered}
$$

According to inequalities (9), (10) and (11), there follows:

$$
C_{1} \leq 1200, C_{2} \leq 2200 \text {, and } C_{i} \geq 0, i=1, \ldots, m=4 \text {. }
$$

Here, $C_{i}, i=1, \ldots, m=4$, according to (12), represent the capacity of the chair lifts that should strive for the highest possible value, while it is not possible to supply the ski slopes with a flow of skiers that exceeds the capacity of them. It should be noticed that the capacity of the ski slope should not be exceeded even in the case of closing one of the ski slopes that is supplied by the same chair lift.

The objective function that represents the maximum flow of skiers on all ski slopes of the ski resort, and should strive for the maximum value, is in the form:

$$
0 \leq F_{c}=\sum_{i=1}^{n=4} C_{i}, i=1 \div 4, F_{c}=C_{1}+C_{2}+C_{3}+C_{4} \rightarrow \max , \text { Figure } 6
$$

Figure 6: Chair ski lifts capacity domain

\section{$F_{C} \neq 0$}

Objective function has its mininum in points $M_{1}$ and $M_{2}$, while its maximum value is reached in $M_{3}$ and $M_{4}$.

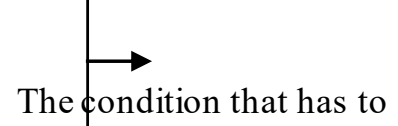
be met is:

$$
C_{-5200}, C_{2}, C_{3}, C_{4}>0
$$

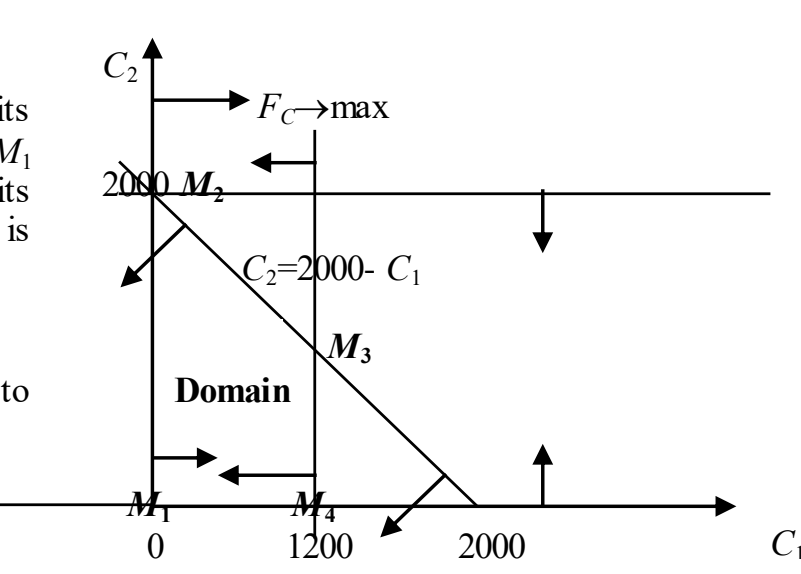

Source: Author's research

Vertex coordinates $M_{1}, M_{2}, M_{3}, M_{4}$ of the domain, formed by closed polyg onal line bounding the domain area that represents the chair lift capacities $C_{1}, C_{2}, C_{3}, C_{4}$ [s kiers/h], (12), are as follows:

$$
\begin{gathered}
M_{i}\left(C_{i 1}, C_{i 2}, C_{i 3}, C_{i 4}\right), i=1,2,3,4 . \\
M_{1}(0,0,1000,2400), M_{2}(0,2000,2000,2400), \\
M_{3}(1200,800,1000,2400), M_{2}(1200,0,1000,2400) .
\end{gathered}
$$


Objective function values in vertexes, according to (13), are as follows in (15):

$$
F_{C M_{1}}=3400, F_{C M_{2}}=4600, F_{C M_{3}}=5400, F_{C M_{4}}=4600 \text {. }
$$

\section{Discussion}

According to previously mentioned in equation (14), the biggest flow on the chair lifts is assumed in vertex $M_{3}$. That concerns the chair lifts capacities in the sizes: $C_{1}=1200, C_{2}=800$, $C_{3}=1000$ and $C_{4}=2400[\mathrm{skiers} / \mathrm{h}],(14)$. This state is considered to be the optimal one.

Efficiency coefficients of the ski slopes according to chair lift capacities are as follows in (16):

$$
\begin{aligned}
& k_{i s 1}=\frac{C_{1}}{S_{1}}=\frac{1200}{1200}=1 \Rightarrow 100 \%, k_{i s 2}=\frac{C_{1}+C_{2}}{S_{2}}=\frac{2000}{2000}=1 \Rightarrow 100 \%, \\
& k_{i s 3}=\frac{C_{3}}{S_{3}}=\frac{1000}{1000}=1 \Rightarrow 100 \%, k_{i s 4}=\frac{C_{2}+C_{3}}{S_{4}}=\frac{1800}{2200}=0.81 \Rightarrow 81 \%, \\
& k_{i s 5}=\frac{C_{2}+C_{3}+C_{4}}{S_{5}}=\frac{4200}{5200}=0.81 \Rightarrow 81 \%, k_{i s 6}=\frac{C_{4}}{S_{5}}=\frac{2400}{2400}=1 \Rightarrow 100 \% .
\end{aligned}
$$

Where: $S_{i}[$ skiers $/ \mathrm{h}], i=1, \ldots, 5$ - capacity of $i$ - ski slope.

\section{Conclusion}

This paper presents a mathematical model, geometric interpretation of linear programming, as well as the Standard Maximum Method and its usage in the field of trans port. The aim of the paper is to analyze the possibility of expanding the potential of Zlatar Ski Center by designing new ski slopes as well as installing additional chair lifts in order to complete the tourist offer of that Center. Additionally, the paper als o provides a model for finding the optimal capacity of additionally designed ski slopes. The ski center is studied as a large systemof internal transport, considering that the analys is of the flow is the main activity.

The obtained results showed that it is possible to confirm the hypothesis stated at the beginning of this paper and get the optimal solution of the expanded capacity of the ski center by applying linear programming and the presented methodology.

This paper als o presents the application of a software program, developed by the authors, to establish thecoefficient of utilization of the ski slopes as well as the entire ski resort. The percentage of skiers who cross from one ski slope to another is also covered, together with "goal" function of the problem and detecting its maximum. Finding the maximum capacity of the projected system is also achieved.

\section{Conflict of interest}

The author(s) declare no conflict of interest.

\section{References}

1. Borrelli F., A. Bemporad A., \& Morari M. (2003). Geometric algorithm for multi parametric linear programming. Journal of Optimization TheoryandApplications, 118 , 515-540. https://doi.org/10.1023/B:JOTA.0000004869.66331.5c

2. Dedijer S. (1983). Osnove transportnih uređaja [Basics oftransport devices]. Beograd, Srbija: Građevinska knjiga. 
3. Jangra, R., \& Kaus hik, S. P. (2021). Estimating carrying capacity in a high mountainous tourist area: A destination conservation strategy. In R. Singh et al. (Eds). Global Geographical Heritage, Geoparks and Geotourism (pp. 427-447). Singapore: Springer. https://doi.org/10.1007/978-981-15-4956-4_22

4. Kasana,H. S., \& Kumar, K. D. (2004). Introductory operations research, theory and applications, geometry oflinear programming . Berlin Heidelberg, Germany: SpringerVerlag.

5. Knijff E. C., \& Oosterhaven, J. (1990). Optimizing tourist policy: A linear programming approach. Regional Studies, 24(1), 55-64. http://dx.doi.org/10.1080/00343409012331345784

6. Mađarević, V. (1969). Rukovanje materijalom [Material handling] . Zagreb, Hrvatska: Tehnička knjiga.

7. Marković, B. (2019a). Metode optimizacije u organizaciji transporta i rukovanja materijalom [Optimization methods in organization of transport and material handling]. Beograd, Srbija: Tehnikum Taurunum.

8. Marković, B. (2019b). Unutrašnji transport [Internal transport]. Beograd, Srbija: Tehnikum Taurunum.

9. Nadler, M. (1973). A geometric interpretation of the SIMPLEX method of linear programming. The Mathematics Teacher, 66(3), 257-264. https://www.jstor.org/stable/27959267

10. Nash, S., \& Sofer, A. (1996). Linear and nonlinear programming. McGraw-Hill Companies, Inc.

11. Poulhès,A.,\& Miria,P. (2017). Dynaski, an agent-based model to simulate skiers in a skiarea. Procedia Computer Science, 109, 84-91. https://doi.org/10.1016/j.procs.2017.05.298

12. Revilloud, M., Loubier, J. C., Doctor, M., Kanevski, M., Timonin, V., \& Schumacher, M. (2011). Artificial snow optimization in winter sport destinations using a multi-agent simulation. In Y. Demazeau et al. (Eds.), Advances on Practical Applications of Agents and Multiagent Systems (pp. 201-210). Berlin, Heidelberg: Springer. http://dx.doi.org/10.1007/978-3-642-19875-5_26

13. Sarbjit, S. (2018). Note on linear programming technique. International Journal of Current Reasearch, 10(2), 65398-65400. https://www.journalcra.com/sites/default/files/issue-pdf/28508.pdf

14. Snow-forecast (2021). Retrieved September 6, 2021 from https://www.snowforecast.com/resorts/Zlatar/

15. Suvajdžić S. (1972). Organizacija ili racionalizacija unutrašnjeg transporta [Organization and rationality of the Internal Transport]. Beograd, Srbija: Univerzitet u Beogradu, Saobraćajni fakultet.

16. Wheeler, S. M. (2012). Understanding and improving the urban environment. metropolitan sustainability. A Volume in Wood Head Publishing Series in Energy, 24. 587-606.

17. Williams, H. P. (2003). Model building in mathematical programming. John Wiley \& Sons.

18. ZlatarInfo Portal, Kornjacos, Tech. (2021). Retrieved September 6, 2021 from https ://zlatarinfo.rs/

19. Zrnić Đ. (1993). Veliki sistemi unutrašnjeg transporta [Big systems of internal transport]. Beograd, Srbija: Univerzitet u Beogradu, Maš inski fakultet.

Received: 24 June 2021; Sent for revision: 3 November 2021; Accepted: 30 November 2021 